\title{
A rare case report of conjoined twins: Thoraco-omphalopagus with anterior abdominal wall defect
}

\author{
Swati Trivedi $^{1 *}$, Santosh Khokher ${ }^{1}$, Shashank Trivedi ${ }^{2}$, Prasoon Rastogi ${ }^{3}$
}

\author{
${ }^{1}$ Department of Obstetrics and Gynaecology, Dr. S. N. Medical College, Jodhpur, Rajasthan, India \\ ${ }^{2}$ Department of Pediatrics, Guru Gobind Singh Govt, Hospital, New Delhi, India \\ ${ }^{3}$ Department of Endocrinology, AIIMS, Jodhpur, Rajasthan, India
}

Received: 02 February 2021

Accepted: 06 March 2021

\author{
*Correspondence: \\ Dr. Swati Trivedi, \\ E-mail: krishnaagnihotri.kgmc@gmail.com
}

Copyright: () the author(s), publisher and licensee Medip Academy. This is an open-access article distributed under the terms of the Creative Commons Attribution Non-Commercial License, which permits unrestricted non-commercial use, distribution, and reproduction in any medium, provided the original work is properly cited.

\begin{abstract}
Conjoined twins are a rare deviation of monozygotic monoamniotic twins which results from fusion of the two at any part of their body. The prognosis is not good and associated with high mortality. Here we report a case of conjoined twin which was referred to our tertiary care hospital as twin pregnancy with impacted breech in obstructed labour. Taking mothers condition into account, she was taken for emergency caesarean section, performing which we realised that it was a conjoined twin. The baby were still born and conjoined at thorax and abdomen (thoraco-omphalopagus) with anterior abdominal wall defect in one and unrevealed sex in other. Current report emphasizes on making an early diagnosis of conjoined twin pregnancy, so that it can be managed at the earliest according to the gestational age.
\end{abstract}

Keywords: Anterior abdominal wall defect, Caesarean section, Case report, Conjoined twin, Obstructed labour, Thoraco-omphalopagus

\section{INTRODUCTION}

Conjoined twin is an exceptionally rare congenital anomaly of two babies physically joined to each other, caused by partial separation of an early embryo after the $13^{\text {th }}$ day of fertilization. Conjoined twinning occurs in 1 in 100 sets of monozygotic twins, 1 in 50,000 gestations or 1 in 250,000 live births. ${ }^{1}$ Around $40 \%$ of the conjoined twins are still born and approximately $35 \%$ die within 24 hours of delivery. ${ }^{2}$ Prognosis to some extent can be related to the vitality of the organs shared and precariousness of the accompanying congenital anomalies.

The cause of conjoined twins is unknown, but two theories have been postulated to explain the origin: fission theory is the traditional one. The fertilized egg is incompletely split, resulting in delayed separation of the embryonic mass after twelfth day of fertilization.
Fusion theory, in which the fertilized egg is completely separated, but the 'stem cells' of one twin fuse with the 'like-stem cells' of other twin, leading to fusion of both twins together. ${ }^{3,4}$

Termination should be offered in early pregnancy if conjoined twins are diagnosed antenatally to prevent the mother from further misery of having a malformed baby after the whole duration of pregnancy.

Overall, approximately 500 cases of conjoined twins are reported in the literature. Here we report a rare but unique case of conjoined twin (thoraco-omphalopagus) with anterior abdominal wall defect in one baby and unidentified sex in other baby. Also, we would like to emphasise that despite the advances in medical sciences, there is still a bridge that needs to be built between the patient's basic medical requirements and the availability of health services. 


\section{CASE REPORT}

A 20 year old G3P2 at 36 week gestational age with 2 full term vaginal delivery was referred to our hospital, from a $\mathrm{CHC}$ as an emergency case on account of impacted twins with breech presentation (Figure 1). Her last pregnancy was 2 years back and her current pregnancy was by spontaneous conception. Her index pregnancy was unsupervised and uninvestigated since the beginning such that the patient wasn't aware that it was a twin pregnancy.

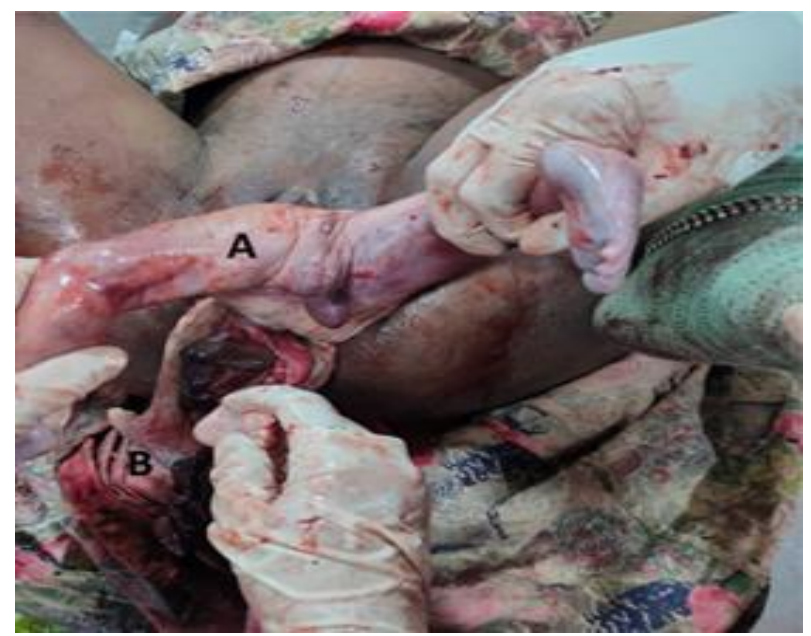

Figure 1: Impacted twin pregnancy with breech presentation showing baby $A$ with thighs and legs outside introitus and baby $B$ with legs outside introitus.

On admission, patient was pale, dehydrated and exhausted. Her BP was normal but pulse rate was 110 per minute. On per abdominal examination, uterus was full of fetus with multiple fetal parts felt. Fetal heart could not be localized with stethoscope or Doppler. On local examination, perineum and thigh of first baby and legs with feet of second baby along with placental tissue were lying outside introitus. On per vaginal examination, buttocks of first baby and thighs of second baby were felt in the birth canal. No active bleeding was present.

Patient's investigations and cross match were send. After explaining poor prognosis for babies and taking high risk consent, patient was shifted immediately for emergency cesarean section. Lower segment cesarean section was performed under general anesthesia. Extraction of the babies was complicated, and it was at that point when we found out that it was a conjoined twin. An assistant was asked to push the baby upwards at the same time as attempting extraction. Feet of second baby were delivered followed by feet and body of first baby, eventually head of first baby and lastly head of second baby. The transverse incision of the uterus has converted into a $\mathrm{T}$ shaped incision with $5 \mathrm{~cm}$ vertical arm extending down into the lower segment (due to the massively stretched out lower segment from obstructed labour). There was no injury to the bladder and the tear was stitched with restoration of complete hemostasis. Patient's intraoperative and postoperative periods were uneventful.

It was a still born conjoined twin with a combined weight of $3.0 \mathrm{~kg}$. First baby was male and the sex of other baby could not be revealed. Placenta was single with single umbilical cord ascertained. On clinical examination, the babies were fused from the level of xiphisternum downwards (thoraco-omphalopagus) with the fold reaching upto the perineum in second baby. First baby was male with anterior abdominal wall defect but the sex of second baby was not identifiable due to the skin fold covering the perineum (Figure 2). The babies were handed over to the relatives as they did not consent for further workup.

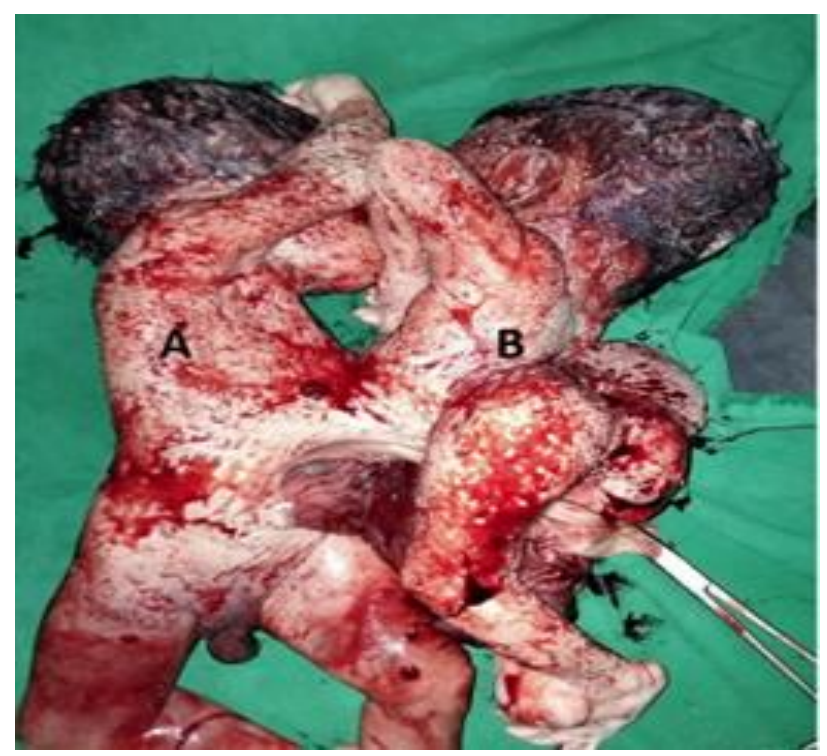

Figure 2: Thoraco-omphalopagus conjoined twin with anterior abdominal wall defect in baby $A$.

There was no history of tobacco or alcohol consumption, any radiation exposure or ovulation inducing drugs or any kind of illicit drug intake during or before pregnancy. No history of twin pregnancy or any congenital anomaly in previous born babies or any such running in the family.

\section{DISCUSSION}

The first case of conjoined twin, born in 1811 who survived to adulthood was reported from Thailand, formerly called Siam, and hence the name Siamese twins. Conjoined twinning is a random event, which is not related to hereditary factors. No effect of maternal age has been found either. ${ }^{5}$ Conjoined twins share a single common chorion, placenta and amniotic sac, thus is exclusively monoamniotic monochorionic. ${ }^{6}$

The outcome of monozygotic twinning and the number of layers of amnion and chorion depends on the time of division of fertilized ovum. As a rule, once any tissue is 
differentiated, it is no longer capable of splitting. The chorion differentiates on day 4 and the amnion on day 8 after fertilization. Hence, if zygotes divide within the first 72 hours after fertilization (which occurs in $25 \%$ of monozygotic twins); two embryos, two amnions and two chorions develop and a diamnionic, dichorionic twin pregnancy evolves. Two distinct placentas or a single fused placenta may develop. If division occurs between 4th and 8th day after fertilization when the chorion has already differentiated (as in $75 \%$ cases), a diamnionic, monochorionic twin pregnancy results. In less than $1 \%$ of monozygotic conceptions, by approximately 8 days after fertilization, the chorion and amnion have already differentiated, and division results in two embryos within a common amnionic sac that is monoamnionic, monochorionic twin pregnancy. But after 13 days of fertilization, division of embryo is usually incomplete and it leads to the development of conjoined twins of various varieties. $^{7}$

The medical term used to describe conjoined twins ends with the suffix "pagus" from the Greek word "fixed". Conjoined twins are classified according to the most prominent site of conjunction: thorax (thoracopagus), abdomen (omphalopagus), sacrum (pygopagus), pelvis (ischiopagus), skull (cephalopagus), and back (rachipagus). Thoracopagus is the most frequent type. $75 \%$ of conjoined twins are seen as thoracoomphalopagus. ${ }^{8}$ The overall survival rate for conjoined twins is approximately $25 \%$. $^{9}$

Conjoined twins are reported as early as the 10th week of gestation. ${ }^{10}$ When the diagnosis of the conjoined twins is made, the type and severity of the abnormality should be assessed with two- and three-dimensional ultrasound, CT scan or MRI. ${ }^{5}$ When severe forms are diagnosed prior to 24 weeks gestation, termination via vaginal delivery should be considered. ${ }^{11}$

Moreover, this case report emphasizes the limitation of health facilities and lack of awareness among patients in developing countries, where the patient didn't bother for even a preliminary ultrasound or antenatal checkup; and hence focuses on the necessity of health facilities to be catered to as many as possible.

\section{CONCLUSION}

Conjoined twins are an extremely rare developmental anomaly with high perinatal mortality and morbidity. Available modalities should be used to diagnose such a pregnancy before viability and termination be offered to the parents at the earliest. This can be made possible by strengthening health care set up and improving patient awareness towards early antenatal assessment as per guidelines This way we can reduce an unnecessary burden of taking the pregnancy to term which carries grave prognosis and adds to maternal morbidity as well; as happened in our case.

\section{Funding: No funding sources \\ Conflict of interest: None declared \\ Ethical approval: Not required}

\section{REFERENCES}

1. Spitz L. Conjoined twins. Prenat Diagn. 2005;25(9):814-9.

2. Jaczyńska R, Niemiec KT, Przybyłkowska M, Dangel J, Zwoliński J, Helwich E, et al. Conjoined twins diagnostic problems, difficult decisions in choosing the most optimal management in one of the rarest pathologies of pregnancy. Ginekol Pol. 2005;76(8):602-11.

3. Weber MA, Sebire NJ. Genetics and developmental pathology of twinning. Semin Fetal Neonatal Med. 2010;15(6):313-8.

4. Machin GA. Heteropagus conjoined twins due to fusion of two embryos. Am $\mathrm{J}$ Med Genet. 1998;78(4):388-90.

5. Sharma M. Conjoined twins-thoraco-omphalopagus (type A). BJR Case Rep. 2015;2(1):20150016.

6. Donald I. Practical obstetric problems. 7th ed. India: Wolters Kluwer; 2014:353-6.

7. Cunningham L, Bloom D, Hoffman C. Obstetrics. 25th ed. USA: MC Graw Hill Education; 2018:8639.

8. Rathod S, Samal S. Conjoined twins: report of two cases and review of literature. Int J Res Med Sci. 2014;2:1203.

9. Stone JL, Goodrich JT. The craniopagus malformation: classification and implications for surgical separation. Brain J Neurol. 2006;129(5):1084-95.

10. Chiabi A, Nkemayim D, Tchokoteu P-F, Guegang EG, Ndeki N N, Minkande JZ, et al. Conjoined twins in Cameroon: issues inherent in diagnosis and management in the African context. Afr J Reprod Health. 2009;13(3):127-35.

11. Sabih D, Ahmad E, Sabih A, Sabih Q. Ultrasound diagnosis of cephalopagus conjoined twin pregnancy at 29 weeks. Biomed Imaging Interv J. 2010;6(4):508 .

Cite this article as: Trivedi S, Khokher S, Trivedi S, Rastogi P. A rare case report of conjoined twins: Thoraco-omphalopagus with anterior abdominal wall defect. Int J Reprod Contracept Obstet Gynecol 2021;10:1724-6. 